\title{
Nitel Makalelerin Yöntem Analizi
}

\section{Method Analysis of Qualitative Articles}

Makale Hakkında
Gönderim Tarihi: 02.12 .2020
Kabul Tarihi: 02.10 .2021
Yayın Tarihi: 01.11 .2021

Anahtar Kelimeler

Nitel desenler

Yöntem

İçerik analizi

Betimsel analiz
Ayşe Betül AKDEMIR ${ }^{1}$, Abdurrahman KILIÇ²

\section{$\ddot{O}_{\text {zet }}$}

Bu çalı̧̧manın amacı nitel araştırma yöntemleri kullanılarak hazırlanan makalelerin yöntemsel analizlerini yapmaktır. Nitel yaklaşımın benimsendiği çalışma iç içe geçmiş tek durum desenine sahiptir. Çalışma grubu amaçlı örnekleme türlerinden maksimim çeşitlilik ve ölçüt örneklem teknikleriyle belirlenmiş olan TR Dizin Sosyal ve Beşerî Bilimler Veri Tabanı Dergi Listesi'nde yer alan 46 egitim bilimleri ve sosyal bilimler dergisi ile bu dergilerin 2019 yılı 1. sayısında yayımlanan, nitel yaklaşımla hazırlanmış 187 makaledir. Çalışma verileri betimsel analiz ve içerik analizi ile çözümlenmiştir. İncelenen makalelerin önemli bir bölümünde nitel araştırma yöntemlerine uygunluk bakımından sorunların olduğu belirlenmiştir. Araştırma kapsamında incelenen makalelerde farkl nitel desenlerin kullanıldiğ makalelerde öne çıkan sonuçlar bu çalışmaların önemli bir kısmında kullanılan desenlerin, seçilme nedeninin yeterince açıklanmadı̆̆l, yanlış isimlendirildiği, kuramsal açıklamaların eksik ya da hatalı olduğu ve hatta bazı çalışmalarda desen bilgisine yer verilmediği yönündedir. Bu araştırmada ulaşılan sonuçlar nitel literatürde yer almayan kimi desenlerin kullanıldı̆̆ını, var olan desenlerin kullanımınin da hatalar barındırdığın ortaya koymaktadır. Bu durum çalışmaların niteliksel olarak yeterli olmadıklarını şeklinde yorumlanabilir.

\section{Abstract}

The purpose of this study is to make methodological analysis of articles prepared using qualitative research methods. The study in which the qualitative approach is adopted has single-case embedded design. It is 187 articles prepared in qualitative approach, published in the first issue of 2019 journals and social sciences journal published in TR Directory Social and Humanities Database Journal List, which is determined by maximum variation sampling and criterion sampling techniques, which are among the sampling types for study groups. The study data were analyzed by descriptive analysis and content analysis. It has been determined that there are problems in terms of compliance with qualitative research methods in a significant part of the articles examined. It was determined that different qualitative designs were used in the articles examined within the scope of the study. The prominent results in the articles reviewed are that the reasons for choosing the patterns used in most of these studies are not sufficiently explained, that they are misnamed, that theoretical explanations are incomplete or erroneous, and even some studies do not include pattern information. The results obtained in this study reveal that some designs that are not included in the qualitative literature are used, and that the use of existing designs contains errors. This situation can be interpreted as the studies are not qualitatively sufficient.

Akdemir, A. B. \& Kılıç, A. (2021). Nitel makalelerin yöntem analizi. Muğla Sıtkı Koçman Üniversitesi Eğitim Fakültesi Dergisi [MSKU Journal of Education], 8(2), 486-502. DOI: $10.21666 /$ muefd. 834707

\footnotetext{
${ }^{1}$ Düzce Üniversitesi, ayseakdemir@duzce.edu.tr, ORCID: 0000-0001-5939-6511

${ }^{2}$ Düzce Üniversitesi, abdurrahmankilic@ duzce.edu.tr, ORCID: 0000-0002-2704-2951
} 
Bilimsel araştırmalarda sağlıklı ve güvenilir sonuçlara ulaşma, araştırmanın amaçlarına en uygun yöntemin belirlemesine ve etkili bir biçimde uygulanmasına bağlıdır. Bu durum tercih edilen bilimsel araştırma yöntemlerinin kuramsal temellerini bilinmesini gerektirmektedir. Russell'e (2019) göre bilim, öncelikle bilgidir; gerçek dünyaya ilişkin güvenilir ve geçerli bilgi edinmenin en güvenilir yoludur. $\mathrm{Bu}$ yönüyle bilim makul bir inanca ilişkin en özlü paradigma olarak nitelendirilir (Gimbel, 2017). Hammaddesi sorular olan bilimsel bilgi (Audi, 2018) insanın, evrendeki örüntüleri, yasaları, düzenlilikleri kavrama ve bunları farklı biçimlerde kullanabilme yeteneğini ifade eder. Bu bağlamda değerlendirildiğinde bilimsel bilgi insanlık tarihinin kalbinde yer alır (Whitfield, 2018). İnsanın varlık sahasına çıktığı günden itibaren meydana getirdiği teknik, araç ve beceri birikimi bilimsel teorilerin ve yöntemlerin gelişmesine kapı aralamıştır (Mason, 2019). İnsanın aynı varlık alanını farklı yönleriyle görme becerisi bilim ve felsefede ilerlemeyi, çeşitliliği ve ilerlemeyi tetikleyici çatışmaları beraberinde getirmiştir (Mengüşoğlu, 2017). Russell (2019) bilimin yükselişinin her ne kadar ilerlemenin gerektirdiği unsurları sağlasa da kendi başına hakiki bir ilerlemeyi garantileyemeyeceğine vurgu yapar. Ona göre yaşama dair dengeli bir bakış açısına ulaşabilmek için bilim ve bilgelik dengesinin kurulması gereklidir (Cevizci, 2014). Aklın dengeleyicisi olarak bilim, fiziksel doğaya ilişkin ilkeleri tam olarak anlamamızı sağlar. Ancak toplumla arasındaki boşluğun felsefe ile doldurulmasına ihtiyaç vardır (Frank, 2017). Yeterli bilimsel formasyona sahip filozoflar şekillenmekte olan bilimin içinde işleyen felsefi kavramları yargılayarak dengeyi sağlarlar (Lecourt, 2013).

İnsan varlığının bir eylemi, bir ürünü olarak bilim, insandan ve değerden tümüyle bağımsız değildir (Guénon, 1990). Ancak kimi zaman düşünceyi dünyevileştirerek, değerler ve hüküm verme ölçütleri üzerinde etki yaratabilmektedir (Moses \& Knutsen, 2020). Ne var ki, değer yargılarına dönük bilişsel işleyiş, sadece ulaşmak istenen amaçları ve bunların altında yatan ideaları anlamakla ve empati kurarak analiz etmekle kalmaz aynı zamanda bunları eleştirel biçimde yargılayabilir de (Weber, 2017). Bilim doğası, kapsamı ve ürettiği teknikle sosyal yaşamı ve geleneksel kurumları değişime itmekte (Gillies, 2018) dolayısıyla insanın fiziksel ve sosyal çevreyle ilişkisini düzenleyerek kendi olma kabiliyetini geliştirmektedir (Russell, 2019). Bu, bilimin insan yaşamı üzerinde yarattığı etkidir (Gillies, 2018). Bu etki bağlamında şekillenen insan hakkında bir şeyler bilmek sosyal bilimlerin hedefidir: Sayısı olmayan ilginç, sistemli, tuhaf, inanılmaz, aşikâr, karmaşık şeyler (Abbott, 2013). Sosyal bilimlerin gündelik bilgi ve doğa bilimiyle nasıl bir ilişki içinde olduğu; sosyal bilimlerin doğa bilimini taklit etmesinin gerekli olup olmadığı türünde tartışmalar bilimsel araştırmaların yöntem ve felsefeleriyle ilgili temelleri ve karşıtlıkları oluştururlar (Sayer, 2019). Benimsenen görüşler, gerçek ve nesnel bir dünyanın var olması bağlamında ontolojik zeminde; dünyayı bilmenin olasıllğı ve bilginin türleri bağlamında epistemolojik zeminde; bilgiyi elde etmek üzere teknik aletler bağlamında yöntembilimsel zeminde karşı karşıya gelirler (Corbetta 2003; Akt. Porta, Keating, 2019). Yaklaşımlara ilişkin tartışmalar genellikle iki temel paradigma odağında kendini gösterir: Pozitiviste karşı hümanist, nicele karşı nitel (Creswell, 2017a).

Pozitivist paradigma, sosyal dünyanın doğal dünyayı tanıma teknikleriyle keşfedebileceğini ve sosyal bilimlerin fen bilimleri metodolojisini kullanılabileceğini savunur. Bu etki ile toplumsal olguların araştırılmasında sosyal bilimcilerin doğa bilimcilerini taklit etmeye çalıştıkları görülmüştür (Guénon, 1990). Pozitivist paradigmanın kırılma noktası (Sayer, 2019) bilimin, tümevarımcıların iddia ettiği gibi gözlemle değil aksine tahminle başladığı fikridir. Bilim insanı bu tahminlerini deney ve gözlemle çürütmeye çalışır. Bu bağlamda 'Bilim, teorilerin yanlışlanmasıyla ilerler' (Popper, 2019). Pozitivist paradigmayı eleştirenlere göre ise sosyal olgular doğa bilimlerinden farklı bir biçimde araştırılmalıdır (Baert, 2017). İnsan hayatı esasen anlam, dil, refleksif düşünce ve iletişim içeren bir hayattır (Benton, \& Craib, 2018). Fiziksel olgular açıklanırken tercih etme, karar verme, niyetlenme gibi zihinsel süreçlere işaret eden yer olmamasına rağmen, toplumsal olgular açıklanırken bunların kullanılması uygun ve gereklidir. Bu önemli bir epistemolojik meseledir (Gordon, 2015). Bu açıdan değerlendirildiğinde toplum bilimlerinde sağlam bir fikir birliğinin sağlanması olağanüstü çetin şartlar gerektirir (Kuhn, 2019).

Pozitivist paradigmaya karşı gelişen yorumlayıcı paradigma (Arthur, Waring, Coe, \& Hedges, 2017) çoğu kez pozitivizme temel ve radikal bir alternatif olarak görülür (Berg \& Lune, 2015; Porta, 2019). Yorumbilim olarak da adlandırılan bu yaklaşım, insanların eylemlerine yükledikleri anlamaları araştırır ve çoğu zaman rasyonalitenin doğasını açıklamaya çalışır (Benton, \& Craib, 2018). Bu bir anlamı diğerinden ayırt etmek için fenomeni bağlı olduğu temel bağlam içerisinde yorumlama zorunluluğu getirir (Moses \& Knutsen, 2020). İnsanların davranış, ürün ve ilişkilerinin anlaşılması, tamamen bunları oluşturan ya da uygulayanların öz anlayışlarının yeniden inşasına dayandığını savunan yaklaşıma göre 
başkalarını anlamak, onların yaptıklarının anlamını anlamakla mümkündür. $\mathrm{Bu}$ ise onların bakış açısından bakarak kazanılabilir (Fay, 2017). Bu bağlamda yorumbilim hiçbir şeyin belirli bir bakış açısından bağımsız yorumlanamayacağına dikkat çekerek, çalışılan kişilerin bağlamdaki bakış açılarını yakalamanın ve açıklamanın birinci öncelik olduğunun altını çizer (Patton, 2018). Böylelikle üzerinde çalışılan hayat hakkında görüş yükselir, çoğaltır ve bilgi gelişerek derinleşir (Charmaz, 2015). Bu çerçevede bakıldığında nitel paradigmanın odağı sosyal fenomen algıdan bağımsız değildir (Habermas, 2011). Bilgi öznel ve sosyal olarak yapılandırılır. Bireysel, sosyal içerik eşsizdir bu nedenle ne genelleme istenir ne de mümkündür. Araştırma, durumları anlama ve farklı aktörlerin bu durum üzerindeki etkisini anlamaya odaklanır. Araştırmacının değer ve inançlarını anlamak, iddialarını anlamak için önemlidir (Arthur vd., 2017).

Nitel paradigma içerisinde canlandırıcı ve zaman zaman da zahmetli bir çeşitlilik bulunur (Patton, 2018). Yöntem olarak da nitelenebilen bu çeşitlilik dünyaya özenle düşünülmüş biçimde yaklaşmayı ifade eder (Sayer, 2019). Ancak yöntembilim, epistemoloji ve kuramlardan bağımsız düşünüldüğünde yöntemler veri elde etmeden öteye geçemez (Porta \& Keating, 2019). Oysaki bilimsel yöntemin insanın kararları üzerinde dinamik ve yaratıcı nitelikte bir etkisi vardır (Mason, 2019). Nitel araştırmaların güçlü yönlerinden biri önceden tespit edilmiş bir hipotez olmaksızın bir duruma tümevarımsal ve doğal araştırma stratejisi ile yaklaşmasıdır. Anlayış ve kuram, alan çalışmalarındaki deneyimlerden ortaya çıkar ve veriler temel alınarak oluşturulur. Problem açık bir zihinle alana nasıl yaklaşılacağıdır. Örneğin fenomenolojide üzerinde çalışılan fenomenin özüne ulaşmak için hem alan çalışması hem de analiz sürecinde önyargılar ve eğilimler hakkında bilgilenmek ve onları göz önüne almak önemlidir (Patton, 2018). Miles ve Huberman (2016) farklı araştırmacılara ait nitel araştırma sinıflamalarını '...olabildiğince kapsamlı ve açıklayıcı' bulmakla birlikte bu sınıflamaların hem farklı nitel araştırmaları tanımlama biçimlerinde hem de onları ayırmak için kullanılan ölçütlerde temel olarak yetersiz kaldıkları sonucuna ulaşmıştır. Onlara göre zihin herhangi birini diğerinden ayırmaya çalıştığında başarısız olmaktadır. Patton'a (2018) göre ise bu karmaşıklık bazı yaklaşımların birleştirilerek uygulanmasından kaynaklanmaktadır. Örneğin herhangi bir araştırmacı heuristik feminist (yönelimsel) çalışabilir yani feminist bakış açısı ile heuristik bir araştırmaya başlayabilir. Nitel desenlerin çeşitliliği altı temel soruya verilen cevaplar ile ayrılmaktadır: (1) Gerçekliğin doğası hakkında nelere inanırız? (2) Bildiğimiz şeyleri nasıl biliriz? (3) Dünyayı nasıl incelemeliyiz/araştırmalıyız? (4) Bilinmeye değer olan şeyler nelerdir? (5) Hangi soruları sormamız gerekmektedir? (6) Araştırmaya kişisel olarak nasıl katılırız?

Nitel desenler problemin belirlenmesiyle başlayan veri toplama, analiz ve raporlama ile devam eden genel araştırma sürecine sahiptir. Fakat farklı ölçülerde, gözlem, görüşme, doküman ve görsel-işitsel materyal ihtiva eden veri toplama araçlarından faydalanırlar (Maxwell, 2018). Desenler arasında örtük benzerlikler dikkate alınmalıdır: Anlatı araştırması, etnografi ve durum çalışması araştırması analiz birimi tek bir kişi olduğunda benzer görülebilir. Ancak toplanması gereken veri ve analiz süreci önemli ölçüde farklılık gösterecektir: Anlatı araştırmasında, katılımcının naklettiği öykülere odaklanılıp kronolojik sıralama yapılırken etnografide bireyin özkültürü bağlamındaki öykülerin ortamına odaklanılır. Durum çalışması araştırmasında çoğunlukla temaya örnek olabilecek tek bir durum belirlenir ve araştırmacı bu duruma ilişkin koşulları ayrıntılı betimler. Yalnızca bir birey üzerinde çalışmak istemesi durumunda önerilecek yaklaşım, anlatı araştırması ya da tek durum çalışmasıdır. Çünkü etnografinin odağı kültürün çok kapsamlı bir resmini sunmaktır (Creswell, 2018).

Bir hayatı araştırmak, kuram oluşturmaktan ya da kültürel bir grubun davranışlarını açıklamaktan daha farklıdır. Nitel desenler özünde örtüşmesine rağmen, kimi yaklaşımların tek disiplinli gelenekleri varken (sosyoloji kökenli kuram oluşturma gibi) kimilerinin daha geniş disiplinler arası arka planı bulunmaktadır. Bir olguyu ya da durumu derinlemesine resmedebilmek için fenomenolojide yalnızca görüşme, durum çalışması araştırmasında ise birden fazla form kullanılır. Veri analizi aşamasında farklılıklar çok barizdir. Kuram oluşturma en spesifik iken anlatı araştırmasının daha az tanımlı olması gibi. Veri analizinde uygulanması gereken basamaklar da değişiklik göstermektedir. Fenomenolojide basamaklar daha kapsamlı iken etnografide birkaç basamak. Tüm yaklaşımlarda ulaşılan sonucu, yazılı rapor, geçirdiği tüm süreçler şekillenir. Buna göre bireyin hayatına dair hikayeler, anlatı araştırması; bir olgunun deneyimine dair özün belirlenmesi, fenomenoloji; görsel bir model yoluyla sunulan bir kuram, kuram oluşturma; aynı kültürü paylaşan bir gruba bütüncül bir bakış, etnografi; bir durum ya da sınırlandırılmış sisteme dair derinlemesine bir çalışma durum çalışmasıdır (Creswell, 2018; Glesne, 2015). 
Kuramsal çerçevede tartışıldığı üzere nitel araştırma yaklaşımı sahip olduğu doğallık ve esneklik sayesinde sosyal araştırmaların özüne daha uygundur. Bu araştırmanın temel amacı nitel araştırma yöntemi ile yapıldığı ifade edilen makalelerin yöntem bölümünün nasıl açıklandığını ortaya koymaktır. $\mathrm{Bu}$ sayede makalelerin nitelik düzeyleri ve yöntem analizleri hakkında fikir sahibi olunması amaçlanmıştır. Eğitim araştırmalarında nitel yaklaşıma olan ilginin her geçen gün artması ve araştırmacıların yöntemin uygulama sürecinde yaşadıkları sorunlar düşünüldüğünde bu çalışmanın alana ilişkin sentez bilgi sunması bakımından nitel yaklaşımı benimseyen araştırmacıların ilgisini çekeceğine ve çalışmalarında rehberlik edeceğine inanıyoruz.

\section{Yöntem}

\section{Araştırma Modeli}

Nitel araştırma yaklaşımına göre temellendirilen bu çalışma durum çalışması desenine sahiptir. Nitel araştırma dünyaya dair yorumlayıcı ve doğal bir yaklaşımdır (Denzin ve Linkoln, 2018). Nitel paradigma içerisinde özgün bir desen olan durum çalışması (Creswell, 2018; Silverman, 2018; Stake, 1995) tek ya da az sayıdaki durumu yakından ve derinlemesine anlama ve ortaya koyma isteğidir (Yin, 2017: 4). Durum çalışması güncel bir olgunun gerçek bağlamında ele alınmasını sağlar (Merriam, 2018). $\mathrm{Bu}$ desen hem betimleyici/açıklayıcı bir araştırma sorusuna cevap arandığı hem de değerlendirmeye ihtiyaç duyulduğu durumlara uygundur (Silverman, 2018; Yin, 2017). Bu çalışmanın analiz birimi nitel yaklaşıma sahip makalelerin yöntem özellikleridir. Durum birden fazla analiz birimi içerdiğinde bu durum içerisindeki alt birim ya da alt birimlere yoğunlaşılır. Bu ise iç içe geçmiş durumları ortaya çıkarır (Yin, 2017). Yöntem kategorilerinin birden fazla olmasından dolayı bu çalışma iç içe geçmiş durum çalışması olarak nitelendirilmiştir. Dolayısıyla bu çalışmanın deseni iç içe geçmiş tek durum deseni olarak belirlenmiştir.

\section{Çalışma Grubu}

Çalışma grubu TR Dizin Sosyal ve Beşerî Bilimler Veri Tabanı Dergi Listesi’nde yer alan 46 eğitim bilimleri ve sosyal bilimler dergisi ile bu dergilerin 2019 yılı 1. sayısında yayımlanan, nitel yaklaşımla hazırlanmış, 187 makaleden oluşturulmuştur. Çalışma grubunun belirlenmesinde amaçlı örnekleme yöntemlerinden maksimum çeşitlilik ve ölçüt örnekleme yöntemlerinden yararlanılmıştır. Nitel araştırmalarda örneklem belirlemenin ilk aşaması kimin ya da neyin araştırma konusu olacağına karar vermektir. Bu amaçla çalışma grubunda bulunması gereken ölçütler veya nitelikler belirlenir. Bu ölçütler araştırmaya dâhil edilecek ve hariç tutulacak veri kaynaklarını seçmede kullanılır (Johnson ve Christensen, 2017). Amaçlı örnekleme, araştırılacak konu, olay ya da olguya ilişkin önemli bilgi kaynaklarına ulaşmada araştırmacıya yardımcı olur ve araştırılması istenen durumların derinlemesine incelenmesine imkân tanır (Patton, 2018). Miles ve Huberman'a (2016) göre, maksimum çeşitlilik örneklemesinin amacı, çeşitlilikleri belgelemek ve önemli genel-geçer kalıpları tanımlamaktır. Ölçüt örnekleme yönteminin temel amacı ise araştırma amaçları doğrultusunda belirlenmiş ölçütleri sağlayan veri kaynaklarından somut veriler elde edilmesidir (Yıldırım ve Şimşek, 2016).

Bu araştırmada çalışma grubunun belirlenmesinde 2016 yılında değişen doçentlik başvuru şartları temel ölçüt alınmıştır (ULAKBİM TR Dizin dergilerinin doçentlik başvuru şartlarına dahil edilmesi). Bu bağlamda TR Dizin veri tabanı kullanılarak 2017-2019 yılları arasında eğitim araştırmaları ve sosyal bilimler alanında 73 dergi belirlenmiştir. Belirlenen aralıkta yapılan tarama sonucunda ulaşılan nitel yöntemle hazırlanmış makale sayısının fazla olması (659 makale) çalışma grubunun sınırlandırılması gerektirmiştir. $\mathrm{Bu}$ nedenle çalışma grubu dergilerin 2019 yılı 1. sayılarında yayımlanan makalelerle sınırlı tutulmuştur (Ek-1). Bu aşamada yayın dili Türkçe olmayan (7 dergi), ilgili sayıda belirlenen kriterlere nitel uygun makale bulunmayan (17 dergi), arşivinde nitel yaklaşımla hazırlanmış makale bulunmayan (1 dergi), veri toplama sürecinde TR Dizin kapsamı dışında olan (1 dergi) ve arşivine ulaşılamayan (1 dergi) çalışma kapsamı dışında bırakılmıştır. Son düzenlemenin ardından çalışma grubu 46 dergi ve bu dergilerde yayımlanmış 187 makale olarak belirlenmiştir. Bu dergiler konu, yayıncı türü ve yayın aralığı bakımından maksimum çeşitlilik göstermektedir. Çalışma grubu kapsamında bulunan dergilere yönelik bilgiler Tablo 1'deki gibidir. 
Tablo 1.

Çalışma Grubunda Bulunan Dergilere Yönelik Bilgiler

\begin{tabular}{|c|c|c|c|c|c|c|c|}
\hline \multirow[t]{2}{*}{ Yayıncı türü } & Üniversite & Dernek & Kişi & Yayınevi & $\begin{array}{l}\text { Resmi } \\
\text { kurum }\end{array}$ & Sendika & Kuruluş/Vakıf \\
\hline & 30 & 5 & 4 & 3 & 1 & 1 & 2 \\
\hline \multirow{2}{*}{$\begin{array}{l}\text { Yayın aralığı } \\
\text { (Y1lda) }\end{array}$} & \multicolumn{2}{|c|}{2 say1 } & \multicolumn{2}{|c|}{3 say1 } & \multicolumn{2}{|c|}{4 say1 } & 6 sayı \\
\hline & \multicolumn{2}{|c|}{20} & \multicolumn{2}{|c|}{12} & \multicolumn{2}{|c|}{11} & 3 \\
\hline
\end{tabular}

Çalışma grubu makalelerinin belirlenmesinde ölçüt örneklem yönteminden yararlanılmıştır. Buna göre makale dahil etme kriterleri: (1) TR Dizin'de taranan eğitim bilimleri ve sosyal bilimler dergilerinde yayınlanmış olma, (2) 2019 yılında yayımlanmış olma, (3) Eğitim araştırması olma, (4) Araştırma makalesi türünde olma, (5) Nitel yaklaşımla hazırlanmış olma, (6) Yayın dili Türkçe olma. Hariç tutma kriterleri ise: (1) Araştırma makalesi türünde yayımlanmasına rağmen yöntem bilgisine yer vermeme, (2) Derleme makalesi türünde olmadır.

\section{Veri Toplama Araçları}

$\mathrm{Bu}$ araştırmanın verileri doküman inceleme yoluyla toplanmıştır. Doküman inceleme, amaçlanan hedefe odaklı bilgi içeren belgelerin özgün kelime ve kavramlar açısından taranmasıdır (Miles ve Huberman, 2016; Neuendorf, 2017). Dokümanlar, nitel araştırmalarda geleneksel veri toplama kaynaklarından biri olarak kabul edilir ve araştırmacılar için hazır bilgi kaynağıdır (Merriam, 2018). Bu araştırmada veri toplama aracı olarak araştırma amaçlarına uygun bir makale inceleme formu (veri formu) hazırlanmıştır. $\mathrm{Bu}$ form; makalenin yayımlandığı dergi kodu, makale kodu, araştırma amacı, araştırma modeli, model tanımı, çalışma grubu, veri toplama yöntemi, veri toplama araçları, verilerin analizi, geçerlik ve güvenirlik gibi yöntem basamaklarına ilişkin bilgilerin tematik çerçeveye göre kaydedilebileceği biçimde düzenlenmiştir. Çalışmanın veri kaynağı olan dergiler D1, D2, D3...; makaleler M1, M2, M3... şeklinde kodlanarak PDF formatında bilgisayar ortamında kayıt altına alınmıştır.

\section{Verilerin Analizi}

Nitel veriler karmaşık durumları aydınlatmaya yönelik güçlü bir potansiyele sahip olmakla birlikte araştırmacıya zengin bir içerik sunmaktadır. Nitel verinin sahip olduğu potansiyel ve içeriğin ortaya çıkması, doğru biçimde analiz edilmesiyle yakından ilişkilidir (Miles \& Huberman, 2016). Bu araştırmanın veri analizinde nitel analiz türlerinden betimsel (tümdengelimsel) analiz ve içerik (tümevarımsal) analiz birlikte kullanılmıştır.

$\mathrm{Bu}$ çalışmada veri analizinin ilk basamağı betimsel analizdir. Betimsel analiz verilerin belirlenmiş temalar çerçevesinde özetlenmesi ve yorumlanmasıdır (Patton, 2018; Yıldırım ve Şimşek, 2016). Buna göre incelenen makaleler, betimsel analiz için gerekli çerçevenin oluşturulması amaciyla hazırlanan makale inceleme formu kullanılarak; araştırma modeli, çalışma grubu, veri toplama yöntemi, veri toplama araçları, verilerin analizi, geçerlik ve güvenirlik bilgilerine göre kodlanmıştır. Ardından formda yer alan analiz birimlerine göre kodlanan veriler düzenlenerek ilk kategoriler oluşturulmuştur. Böylelikle incelenen makalelerin yöntem basamaklarının genel özellikleri/eğilimleri ortaya konulmuştur. Bir sonraki aşamada, veri formunda yer alan analiz birimleri, tercih edilen desen odağında yeniden tasnif edilerek yöntem basamaklarına ilişkin ayrıntılı yeni formlar düzenlenmiştir/oluşturulmuştur. Bu sayede verilerin karşılaştırılması ve ihtiyaç duyulduğunda kontrol edilmesi kolaylaştırılmıştır.

Verilerin betimsel analizinin tamamlanmasının ardından incelenen makalelerin yöntem basamakları ile metodolojik uyumlarının belirlenmesine ihtiyaç duyulmuştur. Bu amaçla veriler tematik içerik analizine tabi tutulmuştur. İçerik analizi metin içeriği toplama ve analiz etme tekniği olarak (Neuman, 2014) farklı alanlarda doküman incelemesi için kullanılır (Neuendorf, 2017; Merriam, 2018). Bu analizle verilerin içinde saklı olan gerçekler (Yıldırım ve Şimşek, 2016) tutarlı ve anlamlı bir biçimde ortaya çıkarılır (Patton, 2018). İçerik analizi araştırma verilerini inceleme, verilerden kod üretme, temaları belirleme, tematik ağlar oluşturma, temaların bütünlüğünü sağlama ve yorumlama basamaklarından oluşur (Miles \& Huberman, 2016; Robson, 2017). Buna göre çalışmada betimsel analizle genel çerçevede düzenlenen veriler içerik analiziyle derinleştirilerek, mevcut verileri açımlayacak kavramlara ve bağlamlara 
ulaşılmıştır. Başka bir ifadeyle betimsel analiz yoluyla tesis edilen verilerin derinlemesine incelenmesini sağlayabilmek amaciyla kavramsal temalar belirlenmiştir.

\section{İnanırlık ve Tutarlılık}

Araştırma çalışma grubunun belirlenmesinde dahil etme ve hariç tutma kriterleri belirlenmiş, bu kriterler bağlamında farklı özelliklerdeki dergilerden veri toplanmıştır. $\mathrm{Bu}$ sayede veri kaynağı çeşitlendirilmiştir. İncelenen makalelere yayınlandıkları dergiler yoluyla ulaşılarak orijinallikleri teyit edilmiştir. İncelenen makalelerin yöntem bölümleri araştırmacı tarafından özenle okunmuştur. Elde edilen veriler araştırmacı tarafından hazırlanan tematik veri formuna uygun biçimde kodlanmıştır. Tematik çerçevede düzenlenerek analiz edilen veriler bilgisayar ortamında kayıt altına alınmıştır. Verilerin analizinde betimsel analiz ve içerik analizini birlikte kullanma suretiyle derinlikli ve bütüncül bir analiz sağlanması amaçlanmıştır. Çalışmaya üç aydan daha uzun bir süre ara verilerek birinci analiz aşamasında olduğu gibi makalelerin yöntem bölümleri özenle okunmuş, veriler kodlanmış ve tüm analiz süreci tekrarlanmıştır. Birinci ve ikinci analiz sonucu elde edilen bulgular karşılaştırılmak suretiyle çalışmanın güvenirliği/inanırlığı artırılmaya çalışılmıştır. Çalışmanın ilk kodlama ve analiz süreci Aralık-Ocak 2019'da ikinci kodlama ve analiz süreci Mayıs-Haziran 2020'da gerçekleştirilmiştir. Kodlar arası uyum yüzdesi Miles \& Huberman formülü kullanılarak belirlenmiş̧ir. Buna göre kodlar arası uyum değeri \%99'dur. Verileri incelenme, ilk ve ikinci kodlama, kodlardan temalara ulaşma, temalar arası ă̆ kurma, bütünleştirme ve yorumlama aşamalarını titizlikle, bilimsel ve sistematik biçimde yürütülmüştür. Verilerin analiz süreci ayrıntılı şekilde açıklanmış sonuçlara nasıl ulaşıldığına ilişkin tüm boyutlar ortaya konulmuştur. Araştırma boyunca her aşamada uzman görüşüne başvurularak analiz sürecinin sarmal biçimde kontrolü sağlanmıştır. Ham veriler ve çözümlemeler tekrar analiz yapılabilecek biçimde korunmuştur. Araştırmada ulaşılan bulgular bilimsel etik kurallarına uygun biçimde raporlaştırılmıştır.

\section{Bulgular ve Yorum}

$\mathrm{Bu}$ bölümünde araştırma verilerinin analiz ile ulaşılan bulgulara yer verilmiştir. Bulgular araştırma deseni, çalışma grubu, veri toplama yöntemi, veri toplama araçları, verilerin analizi ve geçerlikgüvenirlik olmak üzere altı başlık altında tablolar halinde sunulmuştur. Her bir tabloda yer alan bulgular açıklanarak doğrudan alıntılarla desteklenmiştir.

\section{Araştırma Deseni}

İncelenen makalelerde kullanılan desen tercihlerine ilişkin ilişkin bulgular Tablo 2'de sunulmuştur.

Tablo 2.

\begin{tabular}{|c|c|}
\hline Desen & Kod \\
\hline \multirow[t]{6}{*}{ Nitel araştırma } & Nitel araştırma yaklaşımı \\
\hline & Nitel araştırma modeli \\
\hline & Nitel metodoloji \\
\hline & Nitel araştırma yöntemi \\
\hline & Nitel araştırma tekniği \\
\hline & Nitel araştırma ilke ve uygulamaları \\
\hline \multirow[t]{3}{*}{ Betimleyici nitel araştırma } & Betimleyici nitel araştırma deseni \\
\hline & Betimsel ve nitel bir araştırma / çalışma \\
\hline & Nitel verilerle çalışılmış betimsel bir araştırma \\
\hline \multirow[t]{3}{*}{ Temel nitel araştırma } & Temel nitel araştırma yaklaşımı \\
\hline & Temel nitel araştırma deseni \\
\hline & Temel nitel araştırma türü \\
\hline \multirow[t]{9}{*}{ Durum çalışması } & Nitel araştırma yöntemlerinden/yöntemlerle yürütülen durum çalışması modeli \\
\hline & Nitel araştırma modellerinden durum çalışması \\
\hline & Nitel araştırma yaklaşımlarından durum çalışması yöntemi \\
\hline & Nitel araştırma yöntemlerinden örnek olay yöntemi \\
\hline & Nitel durum çalışması deseni \\
\hline & Nitel araştırma desenlerinden durum deseni \\
\hline & Tarama modelinde nitel araştırma yöntemi ve durum çalışması deseni \\
\hline & Nitel bir çalışma ve durum çalışması deseni \\
\hline & Nitel araştırma desenlerinden durum/örnek olay çalışması \\
\hline
\end{tabular}




\begin{tabular}{|c|c|}
\hline & Nitel araştırma metotlarından durum çalıșması deseni \\
\hline & Betimsel nitelikli durum çalışması deseni \\
\hline \multirow[t]{2}{*}{ Çoklu durum } & Nitel araştırma yöntemlerinden durum çalışması deseni \\
\hline & Nitel araştırma yöntemlerinden çoklu durum çalışması \\
\hline Bütüncül çoklu durum & Nitel araştırma yöntemlerinden bütüncül çoklu durum deseni \\
\hline İç içe geçmiş çoklu durum & İç içe geçmiş çoklu durum deseni \\
\hline \multirow[t]{4}{*}{ Bütüncül tek durum } & Temel nitel araştırma yöntemlerinden bütüncül tek durum deseni \\
\hline & Durum çalışması desenlerinden bütüncül tek durum deseni \\
\hline & Bütüncül tek durum çalışması deseni \\
\hline & Durum çalışması çeşitlerinden bütüncül tek durum desen çeşidi \\
\hline \multirow[t]{2}{*}{ İç içe geçmiş tek durum } & Nitel araştırma yöntemlerinden iç içe geçmiş tek durum deseni \\
\hline & Durum çalışmasının iç içe geçmiş tek durum deseni \\
\hline \multirow[t]{3}{*}{ Özel durum } & Nitel araştırma desenlerinden özel durum çalışması \\
\hline & Nitel araştırma yöntemlerinden özel durum çalışması \\
\hline & Nitel araştırmada özel durum çalışması yöntemi \\
\hline Kesitsel durum & Kesitsel durum çalışması \\
\hline \multirow[t]{6}{*}{ Fenomenoloji (olgu) } & Nitel araştırma yöntemlerinden görüngübilim deseni \\
\hline & Nitel araştırma yaklaşımlarından olgubilim deseni \\
\hline & Nitel araştırma desenlerinden fenomenolojik yaklaşım/deseni \\
\hline & Olgubilim (fenomenoloji) araştırma deseni \\
\hline & Desen olarak fenomenolojik durum çalışması \\
\hline & Nitel araştırma deseni, fenomenolojik araştırma modeli \\
\hline \multirow[t]{2}{*}{ Yorumlayıcı (hermeneutik) } & Nitel araştırma yöntemlerinden yorumlayıcı araştırma yaklaşımı \\
\hline & Nitel araştırma yöntemlerinden temel yorumlayıcı nitel araştırma deseni \\
\hline \multirow[t]{2}{*}{ Tarihsel araştırma } & Nitel araştırma yöntemlerinden biri olan tarihsel araştırma \\
\hline & Nitel araştırma metotlarından tarihsel araştırma deseni \\
\hline \multirow[t]{8}{*}{ Eylem araştırması } & Nitel araştırma yaklaşımının bir deseni olan eylem araştırması \\
\hline & Nitel araştırma yöntemlerinden eylem araştırması deseni \\
\hline & Nitel araştırma yöntemlerinden eylem araştırması \\
\hline & Eylem araştırması modeli ile desenleme \\
\hline & Eylem araştırması yaklaşımı \\
\hline & Eylem araştırması biçiminde/olarak desenleme \\
\hline & Eylem araştırması özelliği taşıma \\
\hline & Eylem araştırmasına uygun nitel bir çalışma \\
\hline Katılımcı eylem & Araştırma deseni katılımcı eylem araştırması \\
\hline \multirow[t]{11}{*}{ Doküman analizi } & Nitel yaklaşım çerçevesinde doküman incelemesi \\
\hline & Araştırma modeli doküman incelemesine uygun \\
\hline & Nitel araştırma olup doküman analizi yöntemi \\
\hline & Nitel araştırma yöntemlerinden doküman analizi/incelemesi yöntemi \\
\hline & Nitel araştırma yöntemlerinden doküman incelemesi tekniği \\
\hline & Nitel araştırma yaklaşımlarından doküman analizi tekniği \\
\hline & Nitel araştırma tekniklerinden doküman incelenmesi \\
\hline & Nitel veri toplama tekniğine göre belgesel (doküman) araştırma \\
\hline & Nitel araştırma yöntemi doküman incelemesi deseni \\
\hline & Nitel bir yaklaşımla, belgesel tarama yöntemi \\
\hline & Doküman analizi/inceleme çalışması \\
\hline \multirow[t]{4}{*}{ Tarama } & Nitel bir yaklaşımla gerçekleştirilen tarama modeli \\
\hline & Nitel araştırma desenini içeren tarama modeli \\
\hline & Nitel araştırma yöntemlerinden tarama modeli \\
\hline & Nitel araştırma yöntemini esas alan genel tarama modeli \\
\hline
\end{tabular}

Tanımsız (belirtilmeyen)

Tablo 2'de nitel yöntemle hazırlanan makalelerde kullanılan desenlere ilişkin bulgular sunulmuştur. Buna göre incelenen makalelerde kullanılan desenler: nitel araştırma / temel nitel araştırma, durum çalışması ve türleri (çoklu durum deseni, bütüncül tek durum deseni, özel durum çalışması deseni, iç içe geçmiş tek durum deseni, kesitsel durum çalışması deseni), fenomenoloji (olgubilim), yorumlayıcı (hermeneutik), doküman analizi, tarama, tarihsel, eylem araştırması ve katılımcı eylem araştırmasıdır. İncelenen makalelerde öne çıkan desenler durum çalışması ve temel nitel araştırmadır.

Tablo 2' de dikkat çeken önemli bir nokta nitel veri toplama yöntemi olan doküman analizi ile nicel araştırma deseni olan tarama yönteminin çalışmalarda nitel desen olarak adlandırılması ve kullanılmasıdır. Bununla birlikte incelenen çalışmalarda araştırmacıların araştırma desenlerini tanımlama ve adlandırmada sorunlar yaşadıkları belirlenmiştir. Tablo'da sunulduğu üzere incelenen makaleler arasında desen bilgisi verilmeyen çalışmalar bulunmaktadır. Bundan farklı olarak analizde desenlerine ilişkin hatalı ya da tutarsız bilgiler barındıran çalışmalar da görülmüştür. Örneğin M55' de 
desen tanımı 'Bu çalışma temel nitel araştırma yöntemlerinden bütüncül tek durum deseni kullanılarak hazırlanmıştır.' (M55) şeklinde ifade edilmiş̧ir. Bu durum çalışmada kullanılan desenin nitelik bakımından problemli olduğu, bu yönüyle çalışmaların hata barındırdığı şeklinde yorumlanabilir

\section{Çalışma Grubunun Belirlenmesi}

İncelenen makalelerde kullanılan çalışma grubu belirleme yöntemlerine ilişkin bulgular Tablo 3 'te sunulmuştur.

Tablo 3.

\begin{tabular}{|c|c|c|}
\hline Yaklaşım & & Tür \\
\hline \multirow{27}{*}{ 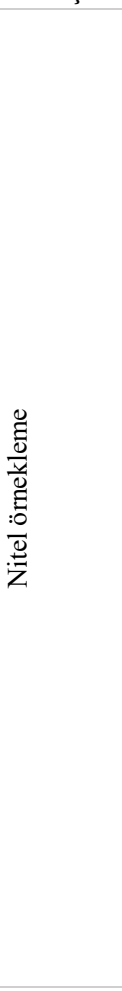 } & \multirow{8}{*}{$\begin{array}{l}\text { Örnekleme } \\
\text { türü eksik } \\
\text { verilen }\end{array}$} & Tesadüfi/Seçkisiz olmayan örnekleme \\
\hline & & Uygun örnekleme \\
\hline & & Amaçlı (yargı) örnekleme yöntemi \\
\hline & & Benzeşik örneklem \\
\hline & & Ölçüt örnekleme yöntemi \\
\hline & & Kolay ulaşılabilir durum örneklemesi \\
\hline & & Kartopu örnekleme \\
\hline & & Maksimum çeşitlilik örneklemesi \\
\hline & \multirow{10}{*}{$\begin{array}{l}\text { Örnekleme } \\
\text { türü ile verilen }\end{array}$} & Amaçl1/amaçsal örnekleme yöntemlerinden ölçüt örnekleme stratejisi/yöntemi/tekniği \\
\hline & & Amaçlı örnekleme yöntemlerinden kritik durum örnekleme \\
\hline & & Amaçlı örnekleme yöntemlerinden maksimum çeşitlilik tekniği/yöntemi \\
\hline & & Amaçlı örnekleme yöntemlerinden/çeşitlerinden/biçimlerinden kolay ulaşılabilir örnekleme tekniği \\
\hline & & Amaçlı örnekleme yöntemlerinden uygun/kazara/kolay ulaşılabilir durum örneklemesi \\
\hline & & Amaçlı örnekleme tekniklerinden tipik durum örneklemesi \\
\hline & & Amaca dayalı tipik durum örneklemesi \\
\hline & & Amaçlı çalışma gruplarından uygun durum çalışma grubu \\
\hline & & Maksimum çeşitlilik sağlamak amacıyla kasıtlı olarak \\
\hline & & Katılımcı amaçlı olarak seçilmiştir \\
\hline & \multirow{4}{*}{$\begin{array}{l}\text { Çoklu } \\
\text { örnekleme } \\
\text { kullanan }\end{array}$} & Kolay ulaşılabilir durum örnekleme ve amaçlı örnekleme türlerinden maksimim çeşitlilik \\
\hline & & Amaçlı örneklem yöntemlerinden ölçüt örnekleme yöntemi ve kolay ulaşllabilir örnekleme \\
\hline & & Amaçlı örnekleme yöntemlerinden olan ölçüt örnekleme ve maksimum çeşitlilik örneklemesi \\
\hline & & Amaçlı örnekleme tekniklerinden ölçüt temelli ve tipik durum örneklemesi teknikleri \\
\hline & \multirow{5}{*}{$\begin{array}{l}\text { Yanlış ifade } \\
\text { edilen/ } \\
\text { Kullanılan }\end{array}$} & Amaçlı örnekleme ve küme örnekleme anlayışı \\
\hline & & Amaçlı örnekleme türlerinden uygun örnekleme \\
\hline & & Amaçlı rastgele örnekleme yöntemi \\
\hline & & Amaçlı örnekleme çeşitliliği sağlayacak şekilde rastgele örnekleme \\
\hline & & Amaçlı örnekleme yöntemlerinden ölçüt örnekleme nitel analiz yöntemi \\
\hline \multirow{4}{*}{$\begin{array}{l}\text { Nicel } \\
\text { örneklem }\end{array}$} & & Tesadüfi/Seçkisiz örnekleme \\
\hline & & Basit seçkisiz örnekleme \\
\hline & & Katmanlı seçkisiz örnekleme \\
\hline & & Kümeleme örneklem \\
\hline \multicolumn{3}{|c|}{ Bilgi verilmeyen } \\
\hline
\end{tabular}

Tablo 3'e göre incelenen makalelerin çalışma grubu belirlemede tesadüfi (seçkisiz) olmayan örnekleme ve türleri ile tesadüfi (seçkisiz) örnekleme türleri kullanılmıştır. Tesadüfi (seçkisiz) olmayan örnekleme türlerinden tercih edilen teknikler uygun örnekleme ve amaçlı örneklemedir. Amaçlı örnekleme ile çalışma grubu belirlenen makalelerde bu örnekleme ait kullanılan alt türler şunlardır: ölçüt örnekleme, kolay ulaş1labilir durum örnekleme, maksimum çeşitlilik, tipik durum örneklemesi, kartopu örnekleme, kritik durum örnekleme, benzeşik örnekleme, amaçlı rastgele örnekleme. Bazı çalışmalarda ise örneklem çeşitlemesine gidilmiştir.

Tablo 3'te nicel araştırmalarda kullanılan örneklem türlerinin tercih edildiğini görülmektedir. Bunlar, tesadüfi (seçkisiz) örnekleme türlerinden, seçkisiz (random/tesadüfi) örnekleme, basit seçkisiz örnekleme, katmanlı seçkisiz örnekleme, kümeleme örneklem, kesitsel örneklemedir. Buna örnek olarak 'Çalışmanın katılımcıları belirlenirken olasılık temelli örnekleme yöntemlerinden biri olan küme örnekleme yönteminden yararlanılmıştır' (M48) ve “Araştırmanın çalışma evrenini, Türkiye'de eğitim yönetimi alanında yazılan ve geleneksel yönetim yaklaşımlarını (bilimsel yönetim, yönetim süreçleri ve bürokrasi) ele alan kitaplar oluşturmaktadır. Çalışma evreni, ulaşılabilir evren olup, araştırmacının doğrudan gözlem veya inceleme yapmasına ya da ondan seçilen bir örnek küme üzerinden inceleme yapmasina olanak vermektedir (M116)" verilebilir. 
Tablo 3'te görüldüğü üzere incelenen çalışmalar arasında örneklem bilgisine yer verilmeyen makaleler bulunmaktadır. Çalışma grubunun araştırma amaçları doğrultusunda belirlendiği düşünüldüğünde, araştırma raporlarının yöntem kısmında bu bilginin verilmemesi ya da eksik verilmesi inanırlığı (iç geçerliliği) zayıflattığ 1 şeklinde yorumlanabilir.

\section{Veri Toplama Yöntemi}

İncelenen makalelerde kullanılan veri toplama yöntemlerine ilişkin bulgular Tablo 4 'te sunulmuştur.

Tablo 4.

\begin{tabular}{|c|c|c|c|}
\hline \multicolumn{2}{|l|}{ Tema } & Alt Tema & Kod \\
\hline \multirow[t]{12}{*}{ Görüşme } & & Strateji & Veri toplama stratejisi olarak görüşme \\
\hline & & Yöntem & Görüşme yöntemlerinden görüşme formu yaklaşımı \\
\hline & & \multirow[t]{4}{*}{ Teknik } & Görüşme tekniği \\
\hline & & & Nitel araştırma veri toplama tekniklerinden görüşme tekniği \\
\hline & & & Yapılandırılmış derinlemesine bireysel görüşsme tekniği \\
\hline & & & Yaşam anlatısı tekniği \\
\hline & \multirow{4}{*}{$\begin{array}{l}\text { Yarı } \\
\text { Yapilandırılmış }\end{array}$} & \multirow[t]{2}{*}{ Yöntem } & Nitel araştırma yöntemlerinden yarı yapılandırılmış görüşme yöntemi \\
\hline & & & Yarı-yapılandırılmış görüşme yöntemi \\
\hline & & Teknik & Yar1-yapılandırılmış, görüşme tekniği \\
\hline & & Tür & Yarı yapılandırılmış görüşme türü \\
\hline & Yapılandırılmış & Teknik & Yapılandırılmış görüşme tekniği \\
\hline & Odak Grup & & Odak grup görüşmeler şeklinde/yoluyla \\
\hline \multirow[t]{6}{*}{ Doküman } & & \multirow[t]{3}{*}{ Yöntem } & Doküman incelemesi/belgesel tarama yöntemi \\
\hline & & & Veri toplama yöntemi olarak doküman incelemesi yöntemi \\
\hline & & & Nitel araştırma yöntemlerinden belge incelemesi yoluyla \\
\hline & & \multirow[t]{2}{*}{ Teknik } & Veri toplama tekniğine göre belgesel (doküman) araştırma \\
\hline & & & Doküman inceleme tekniği \\
\hline & & Diğer & Doküman incelemesi \\
\hline \multirow[t]{2}{*}{ Metafor } & & Yöntem & Metafor analiz yöntemi \\
\hline & & Teknik & Yapılandırılmış metafor tekniği \\
\hline
\end{tabular}

Tanımsız (Belirtilmeyen)

Tablo 4'e göre veri toplama amaciyla görüşme, gözlem, doküman inceleme, metafor kullanıldığı, bununla birlikte veri toplama tekniği tanımsız (belirtilmeyen) çalışmaların da olduğu görülmektedir. Tabloya göre görüşme türlerinde yarı yapılandırılmış görüşme, yapılandırılmış görüşme ve odak grup görüşme tercih edilen yöntemlerdir. Gözlem türelerinden ise yapılandırılmış gözlem veri toplama yöntemi olarak kullanılmıştır. Literatürde yer alan nitel veri toplama araçları gözlem, görüşme ve doküman incelemedir. Bu yöntemler kendi içinde farklılaşabilmektedir. Nitekim nitel araştırma doğası gereği esnek bir yapıya sahiptir. Ancak bulgular incelendiğinde çok sayıda makalede veri toplama yöntemine ilişkin doğrudan bilgi verilmediği, veri toplama araçları üzerinden açıklama yapıldığı görülmüştür. Bu bağlamda araştırmacıların bu konuda yeterince titiz davranmadıkları söylenebilir. Bir başka sorun ise veri toplama araçlarının tanımlanmasıyla ilgilidir. Örneğin; 'Verilerin toplanmasının ilk aşamasında çözümlenecek 100 yerli çocuk tiyatrosu metni literatür taraması ve uzman görüşü alınarak belirlenmiştir' (M28). Uzman görüşü veri toplama yöntemlerinin çalışmaya uygunluğunu belirleme ve çalışmanın tutarlılığının (iç güvenirliğinin) sağlanması amacıyla başvurulan bir yoldur.

\section{Veri Toplama Araçları}

Bu kısımda incelenen makalelerde kullanılan veri toplama araçlarına ilişkin bulgular sunulmuştur.

Tablo 5'e göre makalelerde kullanılan veri toplama araçları: odak grup görüşme, görüşme formu, yarı yapılandırılmış görüşme formu, yapılandırılmış görüşme formu, yapılandırılmamış görüşme soruları, doküman incelemesi, internet/dijital veri tabanı, öğrenci ürünleri/etkinlik kağıtları, öğrenci resimleri/çizimleri, öğrenci yansıma raporu, yansıtıcı günlük, kavram haritası, araştırmacı günlüğü, alan notları, video kayıtları, ses kayıtları, yansıtıcı düşünme formu, gözlem formu, yapılandırılmamış gözlem formu, metafor formu, bilgi formu, öz değerlendirme formu, değerlendirme formu, akran değerlendirme formu, görüş formu, tutum formu, algı formu form, anket, ölçek, mektup/kompozisyon, yapılandırılmış 
test, açık uçlu sorular, rubrik, yaşam anlatısı /aktif ve metodik dinleme, sesli düşünme, sosyal medya grup paylaşımlarıdır.

\section{Tablo 5}

\begin{tabular}{|c|c|c|c|}
\hline Tema & \multicolumn{2}{|l|}{ Alt Tema } & Kod \\
\hline \multirow{49}{*}{$\begin{array}{l}\text { Nitel veri } \\
\text { toplama araçları }\end{array}$} & \multirow{2}{*}{\multicolumn{2}{|c|}{ Görüşme }} & Odak grup görüşmeleri \\
\hline & & & Yapılandırılmamış görüşme soruları \\
\hline & \multicolumn{2}{|l|}{ Gözlem } & Yapılandırılmamış gözlem \\
\hline & \multirow{16}{*}{\multicolumn{2}{|c|}{ Form }} & Görüş ve kişisel bilgi yazılabilecek form \\
\hline & & & Görüşme formu \\
\hline & & & Yarı-yapılandırılmış görüşme formu \\
\hline & & & Yapılandırılmış görüşme formu \\
\hline & & & Açık uçlu sorulardan oluşan yapılandırılmış görüşme formu \\
\hline & & & Öz değerlendirme formu \\
\hline & & & Değerlendirme formu \\
\hline & & & Yansitıcı değerlendirme formu \\
\hline & & & Akran değerlendirme formu \\
\hline & & & Açık uçlu sorudan oluşan görüş formu \\
\hline & & & Açık uçlu soruların yer aldığı bilgi formu \\
\hline & & & Alg1 inceleme formu \\
\hline & & & Açık uçlu sorudan oluşan algı formu \\
\hline & & & Yetişkin eğitimi ve hayat boyu öğrenme formu \\
\hline & & & Değer İnceleme Formu \\
\hline & & & Resim inceleme formu \\
\hline & \multirow{3}{*}{\multicolumn{2}{|c|}{ Araştırmacı ürünleri }} & Araştırmacı gözlem notları \\
\hline & & & Uygulayıcı öğretmen gözlem notları \\
\hline & & & Araştırmacı günlükleri \\
\hline & \multirow{11}{*}{\multicolumn{2}{|c|}{ Katılımcı ürünleri }} & Öğrenci ürünleri/dokümanları/Çalışma kağıtları / etkinlik kâğıtları \\
\hline & & & Öğrenci projeleri /Öğrenci ödevleri \\
\hline & & & Çocuklar tarafından çizilen doğa resimleri \\
\hline & & & Öğrenci yansıtma raporu \\
\hline & & & Yansıtıcı günlük/Bireysel öğrenme günlüğü \\
\hline & & & Mektup \\
\hline & & & Kompozisyon \\
\hline & & & Rol yaprakları değerlendirme \\
\hline & & & Kavram haritası tamamlama \\
\hline & & & Ders kitabından metin \\
\hline & & & Sesli düşünme \\
\hline & \multirow{2}{*}{\multicolumn{2}{|c|}{ Açık uçlu sorular }} & Kendi el yazılarıyla cevapladıkları açık uçlu sorular \\
\hline & & & Amaca bağlı olarak verilen açık uçlu sorular \\
\hline & \multicolumn{2}{|c|}{ Sınav kağıtlar } & Yazılı sınav kağıtları \\
\hline & \multirow{6}{*}{\multicolumn{2}{|c|}{ Test }} & Öğrenci hatalarını saptamak için test \\
\hline & & & Orantısal akıl yürütme testi \\
\hline & & & Yapılandırılmış bir test \\
\hline & & & Konu alan bilgisi testi \\
\hline & & & Bir bilim insanı çiz testi \\
\hline & & & Kapalı uçlu sorular \\
\hline & \multirow{3}{*}{\multicolumn{2}{|c|}{$\begin{array}{ll}\text { Doküman } & \begin{array}{l}\text { Dijital } \\
\text { tabanı }\end{array}\end{array}$}} & Scopus çevrimiçi tarama \\
\hline & & & YÖK tez, ProQuest, Dissertations \& Theses Global \\
\hline & & & Dergipark \\
\hline & & Sosyal medya & İki farklı tartışma forumu \\
\hline & & Basılı yayın & Öğretim Programı \\
\hline & & & Dönemin gazete ve dergileri \\
\hline & & & Ders kitabı inceleme \\
\hline \multirow{5}{*}{$\begin{array}{l}\text { Nicel veri } \\
\text { toplama araçları }\end{array}$} & \multirow{2}{*}{\multicolumn{2}{|c|}{ Anket }} & Açık uçlu sorulardan oluşan bir anket \\
\hline & & & Araştırmacılar tarafindan hazırlanan anket \\
\hline & \multicolumn{2}{|l|}{ Ölçek } & Dört soruluk ölçek \\
\hline & \multicolumn{2}{|c|}{ Tutum Ölçeği } & Kitap Okumaya Yönelik Tutum Ölçeği \\
\hline & \multicolumn{2}{|c|}{ Rubrik } & Birinci el tarihi kaynak analizi değerlendirme rubriği \\
\hline
\end{tabular}

Araştırmada bazı makalelerde veri toplama araçlarının çeşitlendirildiği görülmüştür. M45' de '...yansıtıcı günlük, öz değerlendirme formu, yarı yapılandırılmış görüssme formu ve akran 
değerlendirme formu' kullanıldığı belirtilmiştir. Bazı çalışmalarda ise nicel araştırmalarda kullanılan anket, ölçek vb. araçların tercih edildiği belirlenmiştir. Bulguya ilişkin doğrudan alıntı şöyledir: '... 'Okuma Alışkanlığını Belirleme Anketi' ve ... 'Kitap Okumaya Yönelik Tutum Ölçeği' kullanılmıştır. Ayrıca yapılan her okuma çemberi etkinliği sonunda öğretmen adaylarının okuma çemberinde yapılan etkinliklerde başarılı olup olmadığını belirlemek için düzenlenen 'okuma çemberlerini değerlendirme' ve 'öz değerlendirme' formlanı kullanılmıştır' (M31).

İncelenen makalelerin bir kısmında veri toplama araçlarına ilişkin kuramsal, açıklayıcı ve net bir bilgiye ulaşılamamıştır. Bulguya örnek olarak 'Uzman öğretim üyesiyle ortak fikir sonucunda, ortaokul altıncı sınıf öğrencilerine kompozisyon yazdırılmasına karar verilmiştir.' (M29) ifadesi gösterilebilir. Veri toplama yöntemleri ve veri toplama araçlarına ilişkin bulgular birlikte değerlendirildiğinde incelenen bu nitel çalışmaların tutarlılık (iç güvenirlik) şartını sağlamada sorunlu olduğu söylenebilir.

\section{Veri Analizi}

Bu kısımda incelenen makalelerde kullanılan veri analizi tekniklerine ilişkin bulgular sunulmuştur.

Tablo 6.

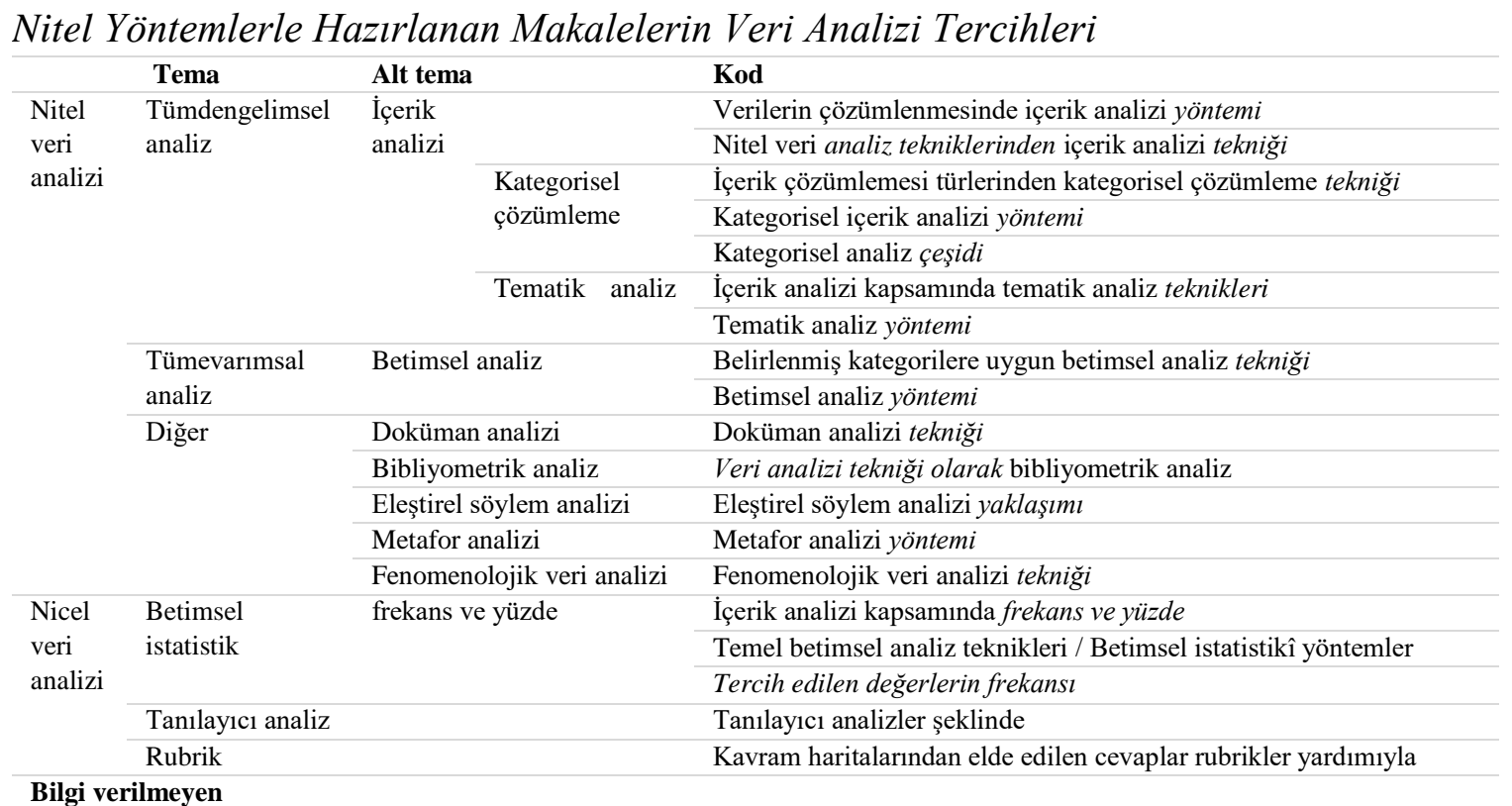

Tablo 6'ya göre nitel makalelerde tercih edilen analiz teknikleri şunlardır: İçerik analizi (tümdengelimsel analiz), betimsel analiz (tümevarımsal analiz), doküman analizi, bibliyometrik analiz, eleştirel söylem analizi, metafor analizi, betimsel istatistik/frekans ve yüzde, fenomenolojik veri analizi, rubrik, tanılayıcı analiz. Bu analiz çeşitliliği içerisinde öne çıkan veri analizi türleri içerik analizi (tümdengelimsel analiz) ve betimsel analiz (tümevarımsal analiz) olmuştur. İncelenen makaleler içinde nitel veri analiz teknikleri ile nicel analiz tekniklerinin de kullanıldığı da görülmüştür. Örneğin; M63' de veri toplama aracı olarak 'Yapılandırılmış görüşme formu, öğrenci günlükleri, ölçme değerlendirme rubriği ve öğrencilerin somut çalışmaları' kullanılmış '...tercih edilen değerlerin frekansı hesaplanmıştır. ...betimsel analiz ...sınıflandırılmış ve sayısal hale dönüştürülmüştür’ betimsel analizle çözümlenen veriler betimsel istatistikle nicel veriye dönüştürülmüştür.

İçerik analizi ile elde edile verilerin nicele dönüştürülmesine örnek olarak ise; 'içerik çözümlemesi ile çözümlenmiş ve elde edilen sonuçlar betimsel istatistikî yöntemler (frekans ve yüzde) kullanılarak sunulmuştur' (M91) verilebilir. İncelenen makaleler arasında verilerin analizine ilişkin kuramsal, açıklayıcı ve net bir bilgi verilmeyen çalışmalar da bulunmaktadır. 


\section{Geçerlik ve Güvenirlik}

Bu kısımda incelenen makalelerde geçerlik-güvenirlik çalışmalarına ilişkin bulgular sunulmuştur.

Tablo 7.

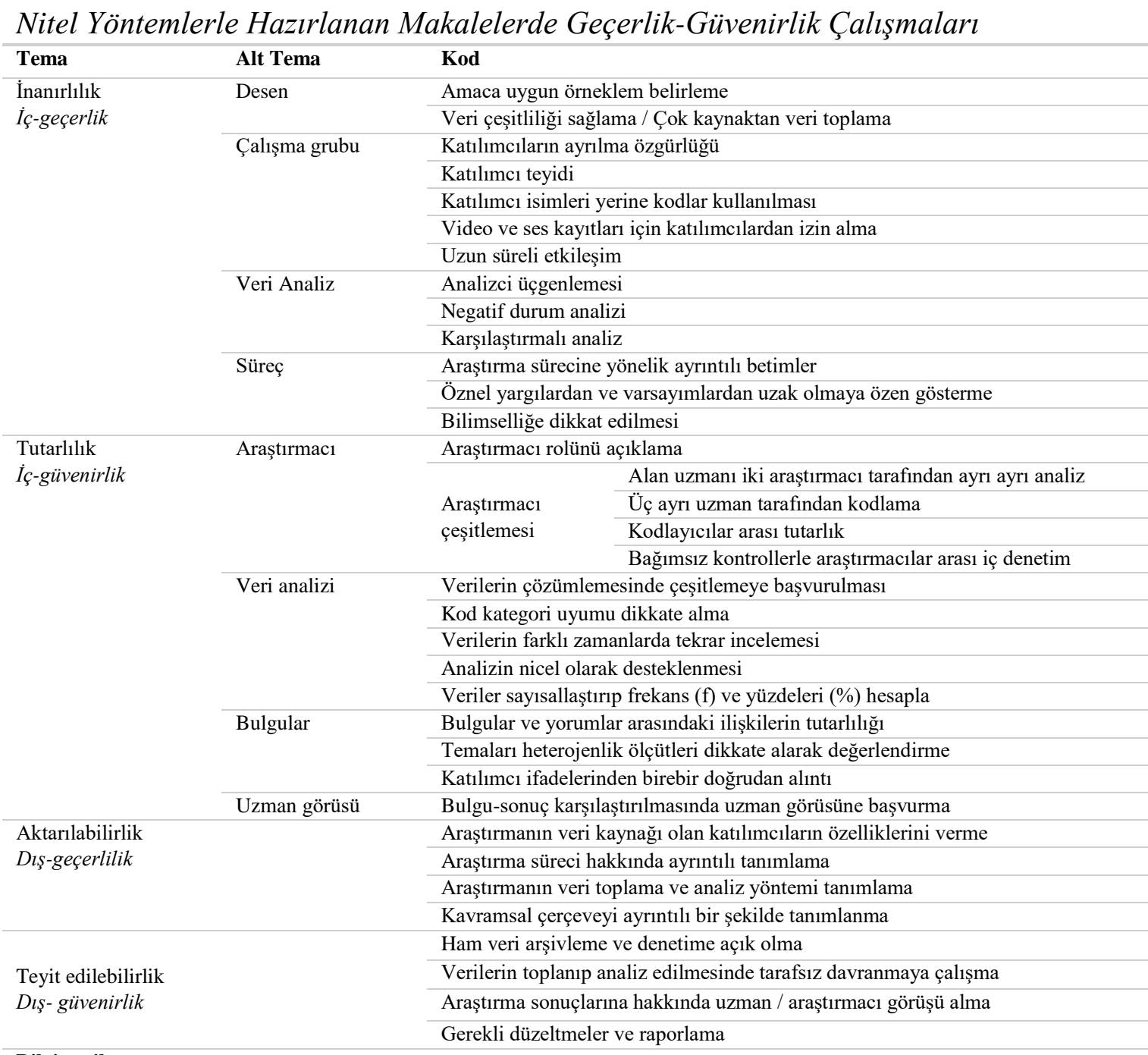

Bilgi verilmeyen

Tablo 7'ye göre makalelerin geçerlik-güvenirlik çalışmaları inandırıcılık, tutarlılık, aktarılabilirlik, teyit edilebilirlik temaları altında toplanmıştır. İnandırıcılık temasını oluşturan bulgular incelendiğinde, amaca uygun örneklem belirleme, uzun süreli etkileşim, katılımcıların ayrılma özgürlüğü, katılımcı teyidi, analizci üçgenlemesi, negatif durum analizi, karşılaştırmalı analiz gibi yöntemlerle inandırıcıllığın sağlanmaya çalışıldığg görülmüştür. Bu temaya ilişkin doğrudan alıntı şöyledir: '...Uzun süreli etkileşim, katılımcıların ayrılma özgürlügüu, verilerin çözümlemesinde çeşitlemeye başvurulması, araştırma sürecine yönelik ayrıntılı betimler...' (M1). Tutarlılık temasının oluşturan bulgular incelendiğinde, verilerin çözümlemesinde çeşitlemeye başvurulması, uzman görüşü, bulgular ve yorumlar arasındaki ilişkilerin tutarlılı̆̆ı, temaları heterojenlik ölçütleri dikkate alarak değerlendirme, kod kategori uyumu dikkate alma, veriler sayısallaştırıp frekans (f) ve yüzdeleri (\%) hesapla, analizin nicel olarak desteklenmesiyle araştırma güvenirliğini artırmaya çalışma, katılımcı ifadelerinden birebir doğrudan alıntı gibi yöntemlerle tutarlılık kazandırılmaya çalışıldığ '...kategorilere ait frekanslar ve yüzdeler verilerek analizin nicel olarak desteklenmesiyle araştırmanın güvenirliği artırılmaya çalışılmıştır.' (M129) verilebilir. Aktarılabilirlik temasında, araştırmanın veri toplama ve analiz yöntemi tanımlama, verilerin analizinde kullanılan kavramsal çerçeve ayrıntılı bir şekilde tanımlanma vb. çalışmalarla aktarılabilirliğin sağlanmaya çalışıldığı görülmüştür. Bu temaya iliş̧kin doğrudan alıntı şöyledir: 'Araştırmanın dış geçerliliği için mesleklerinin ilk yılını çalışan öğretmenler ve farklı hizmet yıllarına sahip öğretmenler amaca uygun olarak seçilmiştir’ (M111). Teyit 
edilebilirlik Ham verilerin arşivlenmesi ve gerekli görüldüğü takdirde denetime açık olması, verilerin toplanıp analiz edilmesinde tarafsız davranmaya çalışma, araştırma sonuçlarına hakkında uzman / araştırmacı görüşü alma, gerekli düzeltmelerden sonra analiz son haline getirilerek raporlaştırılmıştır. Bu temaya örnek olarak ise; 'Araştırmanın dış güvenirliğini (teyit edilebilirliğini) artırmak amacıyla da bir fen eğitimcisi bu çalışmanın ham verilerini, yöntemini ve bulgularını tutarlık bakımından incelenmiştir' (M137) verilebilir.

Geçerlik-güvenirliğe ilişkin bulgular genel olarak değerlendirildiğinde bazı makalelerde sadece kodlayıcılar arası uyum değerinin verilmekle yetinildiği araştırma sürecine ilişkin bilgi verilmediği görülmüştür. Bunun dışında azımsanmayacak sayıda makalede geçerlik ve güvenirliğe ilişkin bilgiye yer verilmemiş olması bu çalışmaların nitelik bakımından.

$\mathrm{Bu}$ araştırmada nitel araştırma yaklaşımına sahip makalelerin nitelik düzeylerini belirleme ve metodolojik analizine odaklanılmıştır. Bu amaç çerçevesinde incelenen makaleler araştırma deseni, çalışma grupları, veri toplama yöntemleri veri toplama araçları ile geçerlik-güvenirlik özellikleri bakımından değerlendirilmiştir.

\section{Tartışma ve Sonuç}

$\mathrm{Bu}$ araştırmada nitel araştırma yaklaşımına sahip makalelerin nitelik düzeylerini belirleme ve metodolojik analizine odaklanılmıştır. Bu amaç çerçevesinde incelenen makaleler araştırma deseni, çalışma grupları, veri toplama yöntemleri veri toplama araçları ile geçerlik-güvenirlik özellikleri bakımından değerlendirilmiştir.

Araştırma kapsamında incelenen makalelerde araştırma konuları bağlamında farklı nitel desenlerin kullanıldığı belirlenmiştir. Bu desenler nitel araştırma/temel nitel araştırma, durum çalışması (çoklu durum deseni, bütüncül tek durum deseni, özel durum çalışması deseni, iç içe geçmiş tek durum deseni, kesitsel durum çalışması deseni), fenomenoloji/olgubilim, yorumlayıcı/hermeneutik, doküman analizi, tarama, tarihsel, eylem araştırması ve katılımcı eylem araştırmasıdır. İncelenen makalelerin önemli bir kısmında; kullanılan desenlerin seçilme nedeninin yeterince açıklanmadığ ${ }_{1}$, desenlerin yanlış isimlendirildiği, desene ilişkin kuramsal açıklamaların eksik ya da hatalı olduğu ve hatta bazı çalışmalarda desen bilgisine dahi yer verilmediği görülmüştür. İncelenen çalışmalardan pek azı literatüre uygun bir metodolojiye sahiptir. İlgili literatürde nitel araştırma desenlerinin çeşitliliği dikkat çekici düzeydedir. Araştırmacılar tarafından farklı sınıflama ve tipolojiler oluşturulmuş (Creswell, 2018) ancak desenler üzerinde tam bir uzlaşı sağlanamamıştır (Miles ve Huberman, 2016). Bunun başlıca nedeni farklı desenlerin birleştirilerek yeni başlık altında kullanılabilmesidir (Patton, 2018). Tüm bu çeşitliliğe rağmen bazı yaklaşımlar diğerlerine göre daha fazla ön plana çıktı̆̆ görülmektedir (Creswell, 2018; Merriam, 2018). Durum çalışması (Creswell, 2018; Glesne, 2015; Denzin ve Linkoln, 2018; Saldana, 2011; Stake, 1995; Yin, 2018), etnografi (Creswell, 2018; Glesne, 2015; Patton, 2018; Strauss ve Corbin, 1998), fenomenoloji (Creswell, 2018; Patton, 2018; Strauss ve Corbin, 1998), kuram oluşturma (Creswell, 2018; Glesne, 2015; Denzin ve Linkoln, 2018; Morse, 2016; Patton, 2018; Saldana, 2011; Strauss ve Corbin, 1998) eylem araştırması (Glesne, 2015; Merriam, 2018) gibi. Bu araştırmada nitel literatürde yer almayan desenlerin araştırma deseni olarak kullanıldığı, var olan desenlerin kullanımının da hatalar barındırdığı sonucuna ulaşılmıştır. Bu bağlamda araştırmacıların nitel araştırma bilgilerinde eksiklerin olduğu söylenebilir.

Araştırmanın örneklem seçimine ilişkin sonuçlarına göre nitel çalışmalarda örneklem yönelimi tesadüfi olmayan örnekleme türlerinden, uygun örnekleme ve amaçlı örneklemedir. Amaçlı örnekleme yöntemlerinden ise ölçüt örnekleme, kolay ulaşılabilir durum örnekleme, maksimum çeşitlilik, ön plana çıkan tekniklerdir. Araştırmada bazı çalışmalarda örneklem çeşitlemesine gidildiği görülmüştür. Çeşitleme, yöntemleri birleştirerek çalışmayı güçlendirir (Patton, 2018). İncelenen makalelerin bazılarında nicel araştırmalarda kullanılan örneklem türlerinin tercih edildiği belirlenmiştir. Nitel araştırmacılar ne rastgele seçimi anlamlı kılacak kadar büyük grupla çalışırlar ne de genelleme yapmayı amaçlarlar (Glesne, 2015). İstatistiksel anlamda genelleme nitel araştırmaların bir özelliği olmadığı için olasılıklı örnekleme nitel araştırmalarda gerekli değildir (Merriam, 2018). Yorumlayıcı gelenekte araştırmacılar her durumu amaçlı olarak seçerler (Creswell, 2017a; Patton, 2018). Bu yüzden en uygun örnekleme stratejisi olasılıksız örneklemedir. Bunun en yaygın biçimi de amaçlı örneklemdir (Patton, 2018). İncelenen makalelerde arasında örnekleme bilgisi verilmeyen çalışmalar bulunmaktadır. Araştırmacının bir problemi en iyi aydınlatması örneklem seçimine bağlıdır. Bu seçim bir bakıma 
ulaşacağı sonuçları ve bunlar konusunda ne kadar güven duyulacağını sınırlandırır. Bu bağlamda örnekleme yani veri toplamayı sınırlandırma analiz için önemli bir basamaktır (Maxwell, 2018; Merriam, 2018; Miles ve Huberman, 2015).

Araştırmanın veri toplama yöntemlerine ilişkin sonuçlarına göre nitel çalışmaların veri toplama yöntemleri: yarı yapılandırılmış görüşme, yapılandırılmış görüşme ve odak grup görüşme, gözlem, yapılandırılmış gözlem, doküman inceleme, literatür tarama, belgesel tarama, metafor analiz yöntemi, yapılandırılmış metafor tekniği, internet, uzman görüşüdür. İncelenen makalelerde belli bir kısmında veri toplama yöntemleri, veri toplama araçları ve veri toplama araçlarının geliştirilme süreçlerine ait kavramların birbirinin yerine kullanıldığı görülmüştür (metafor analiz yöntemi, yapılandırılmış metafor tekniği, internet, uzman görüşü vb.). Bununla birlikte makalelerin çoğunda veri toplama yöntemine ilişkin doğrudan bilgi verilmeden veri toplama araçları üzerinden açıklamaya gidilmiştir. Veri toplama yöntemi terim olarak araştırmacının araştırma sorularını cevaplayabilmek için nasıl veri topladığını belirtir (Christensen, Johnson ve Turner 2015). Başka bir ifade araştırma soruları ve araştırma stratejisi hakkındaki kararlara bağlı olarak en uygun yöntemin hangisi olduğu sorusunu sormaktır (Robson, 2017).

Araştırmanın veri toplama araçlarına ilişkin sonuçlarda bazı çalışmalarda veri toplama araçlarının çeşitlendirildiği görülmüştür. Çeşitleme idealdir (Patton, 2018). Bazı çalışmalarda ise nicel araştırmalarda kullanılan anket, ölçek vb. araçların tercih edildiği belirlenmiştir. Miles ve Huberman (2015, s.35)'göre önceden desenlenmiş ve yapılandırılmış araçlar araştırmacıda sahaya dönük körlük oluşturur. Genellikle bağlamdan uzak olup evrensellik, tek biçimlilik ve karşılaştırılabilirlik gibi önceliklerin peşine düşer. Saha çalışması notlar almayı, olayları kaydetmeyi (sohbetler, toplantılar), belge toplamayı (doküman, ürün, eser) içerir. İncelenen makalelerin bazılarında veri toplama araçlarına ilişkin kuramsal, açıklayıcı ve net bir bilgiye ulaşılamamıştır. Veri toplama yöntemleri ve veri toplama araçlarına ilişkin bulgular birlikte değerlendirildiğinde incelenen bu nitel çalışmaların tutarlılık (iç güvenirlik) şartını sağlamada sorunlu olduğu söylenebilir. Araştırmanın veri analizine ilişkin sonuçlarına göre nitel çalışmalarda en sık kullanılan analiz tekniği içerik analizi (tümdengelimsel analiz) ve betimsel analizdir (tümevarımsal analiz). İncelenen bazı çalışmalarda nitel veri analiz teknikleri ile nicel analiz tekniklerinin de kullanıldığı görülmüştür. Bu nicel veri toplama araçları kullanımının doğal bir sonucudur. İncelenen bazı makalede veri analizine ilişkin bilgiye ulaşılamamıştır.

Araştırmanın geçerlik-güvenirlik yönelimlerine ilişkin sonuçlarına göre nitel araştırmalarda inandırıcılık, tutarlılık, aktarılabilirlik, teyit edilebilirlik sağlanmaya çalışılmıştır. Ancak bazı makalelerde sadece kodlayıcılar arası uyum hesaplamasına gidildiği geçerlik-güvenirlikle ilgili açıklama yapılmadığı belirlenmiştir. Bunların dışında önemli sayıdaki makalede geçerlik güvenirliğe ilişkin bulguya ulaşılamamıştır. Nitel araştırmalarda geçerlik belirli süreçler vasıtasıyla bulguların doğruluğu için araştırmacı kontrolünü ifade ederken nitel güvenirlik, farklı projeler ve araştırmacılar açısından araştırmacının yaklaşımının tutarlılığını işaret etmektedir (Creswell, 2017a).

Elde edilen sonuçlar genel olarak değerlendirildiğinde nitel yaklaşımı benimseyen araştırmacıların önemli bir kısmının bu yaklaşıma ilişkin kavram yanılgılarının olduğu; çalışmaların yöntem bölümlerinin metodolojik ve niteliksel olarak sorunlar barındırdığı dolayısıyla çalışmaların doğru biçimde yapılandırılamadığı söylenebilir. Bu sonuçlar odağında nitel araştırma yöntemlerini kullanacak araştırmacılara ilgili literatürü karşılaştırmalı olarak incelemeleri önerilebilir. Temel kaynaklara inilerek nitel paradigmanın araştırmacılara sağladığı çeşitlilik, esneklik ve derinlik içselleştirilebilir. Bununla birlikte tecrübe kazanmaya yönelik pilot çalışmalar planlanabilir. Böylece daha nitelikli ve sistematik çalışmaların yapılandırılması sağlanabilir.

\section{Kaynakça}

Arthur, J., Waring, M., Coe, R., \& Hedges L. V (2017). Eğitimde araştırma yöntemleri ve metodolojileri (A. Erözkan ve E. Büyüköksüz, Çev. Ed.). Ankara: Anı Yayınları.

Audi, R. (2018). Epistemoloji-Bilgi teorisine çağdaş bir giriş (H.Y. Başdemir, Çev. Ed.). Ankara: Nobel Akademik Yayıncilık.

Abbott, A. (2013). Disiplinlerin kaosu (S. Gürses, Çev.). İstanbul: Küre Yayınları

Baert, P. (2017). Sosyal bilimler felsefesi: Pragmatizme doğru (Ü. Tatlıcan, Çev.) İstanbul: Küre Yayınları.

Benton, T., \& Craib, I., (2018). Sosyal bilim felsefesi -Toplumsal düşüncenin felsefi temelleri (Ü. Tatlıcan ve B. Binay, Çev.). Bursa: Sentez Yayınları. 
Berg, B., \& Lune, H. (2015). Sosyal bilimlerde nitel araştırma yöntemler (H. Aydın, Çev.Ed.). Konya: Eğitim Yayınevi.

Best, J. W., \& Kahn, J. K. (2017). Eğitimde araştırma yöntemleri (O. Köksal, Çev.Ed.). Konya: Eğitim Yayınevi.

Cevizci, A. (2014). Felsefe tarihi -Thales'ten Baudrillard'a (5. Bask1). İstanbul: Say Yayınları.

Creswell, J. W. (2017a). Araştırma deseni nitel, nicel ve karma yöntem yaklaşımları (S.B. Demir, Çev.Ed.). Ankara: Eğiten Kitap.

Creswell, J. W. (2017b). Nitel araştırmacılar için 30 temel beceri (H. Özcan, Çev.). Ankara: Anı Yayıncilik.

Creswell, J. W. (2018). Nitel araştırma yöntemleri -Beş yaklaşıma göre nitel araştırma ve araştırma deseni (M. Bütün ve S. B. Demir, Çev.Ed). Ankara: Siyasal Kitapevi.

Christensen, L. B., Johnson, R. B., \& Turner L. A. (2015). Araştırma Yöntemleri Desen ve Analiz. (A. Aypay Çev.Ed.). Ankara: Anı Yayıncılık.

Denzin, N. K., \& Lincoln, Y.S. (2018). Introduction: The discipline and practice of qualitative research. The SAGE Handbook of qualitative research (5th ed., pp 29-55). Thousand Oaks, California: Sage Publication.

Charmaz, K (2015). Gömülü (grounded) teori yapılandırması - Nitel analiz uygulama rehberi (R. Hoş, Çev.Ed). Ankara: Seçkin Yayıncılık.

Fay, B. (2017). Çağdaş sosyal bilimler felsefesi -Çok kültürlü bir yaklaşım (İ. Türkmen, Çev.). İstanbul: Ayrintı Yayınları.

Frank, P. (2017). Bilim felsefesi bilim ile felsefe arasındaki bă̆ (D. Kadığlu, Çev.). İstanbul: Ay Yayınlar1.

Glesne, C. (2015). Nitel araştırmaya giriş (A. Ersoy ve P. Yalçınoğlu, Çev.Ed.). Ankara: Anı Yayınları.

Gillies, D. (2018). Yirminci yüzyılda bilim felsefesi dört ana tema (M. Tuncel). Ankara: Nobel Yayınc1lik.

Gimbel, S. (2017). Bilimsel yöntemin izinde -Bilim felsefesinin ögretilmesinde yeni bir yaklaşım (Ö. Ünlü, Çev.). Ankara: Dipnot Yayınları.

Gordon, S. (2015). Sosyal bilimler tarihi ve felsefesi (H. Kösebalaban ve Ü. Tatlıcan, Çev.). İstanbul: Küre Yayınları.

Guénon, R. (1990). Niceliğin egemenliği ve çağın alametleri (M. Kanık, Çev.). İstanbul: İz Yayıncılık. Habermas, J. (2011). Sosyal bilimlerin mantı̆̆ üzerine (M. Tüzel, Çev.). İstanbul: Kabalcı Yayınevi.

Johnson, B. \& Christensen, L. (2017). Educational research quantitative, qualitative, and mixed approaches (6th ed.) Thousand Oaks, California: Sage Publication.

Kuhn, T.S. (2019). Bilimsel devrimin yapısı (N. Kuyaş, Çev.). İstanbul: Kırmızı Yayınları.

Lecourt, D. (2013). Bilim felsefesi (I. Ergüden, Çev.). Ankara: Dost Kitapevi Yayınları.

Mason, S.F. (2019). Bilimler tarihi (U. Daybelge, Çev.) Ankara: Türk Tarih Kurumu Yayınları.

Maxwell, J. A. (2018). Nitel araştırma tasarımı -Etkileşimli bir yaklaşım (M. Çevikbaş, Çev. Ed.). Ankara: Nobel Akademik Yayıncılık.

Mengüşoğlu, T. (2017). İnsan felsefesi, (2. basım). İstanbul: Doğu Batı Yayınları

Merriam, S.B. (2018). Nitel araştırma desen ve uygulama için bir rehber (S. Turan, Çev.). Ankara: Nobel Akademik Yayıncılık.

Miles, M.B. \& Huberman, A.M. (2016). Nitel veri analizi (S. Akbaba Altun ve A. Ersoy, Çev.Ed). Ankara: Pegem Akademi.

Morse, J. M. (2016). Developing grounded theory the second generation. New York: Routledge.

Moses, J.W \& Knutsen, T.L. (2020). Bilmenin yolları-Toplumsal ve siyasal araştırmalarda rakip metodolojiler. (K. İlbaşı ve E.B. Ersöz). İstanbul: Küre yayınları.

Neuendorf, K. A. (2017). The content analysis guidebook. (2th ed.). Thousand Oaks, California: SAGE Publications.

Neuman, W. L. (2014). Toplumsal araştırma yöntemleri -Nitel ve nicel yaklaşımlar 2.cilt (S. Özge, Çev.). Ankara: Siyasal Yayınevi

Patton, M. Q. (2018). Nitel araştırma ve değerlendirme yöntemleri. (M. Bürün ve S.B. Demir, Çev. Ed.). Ankara: Pegem Akademi.

Popper, K. R. (2019). Bilimsel araştırmanın mantığı (İ. Aka ve İ. Turan, Çev.). İstanbul: Yapı Kredi Yayınları. 
Porta, D. (2019). Karşılaştırmalı analiz: Vaka-yönelimliye karşı değişken-yönelimli araştırma (S. Gürses, Çev.). D. della Porta ve M. Keating (Ed.). Epistemolojik bir giriş. Sosyal bilimlerde yaklaşımlar ve metodolojiler çoğulcu bir perspektif (s. 241-269) içinde. İstanbul: Küre Yayınları.

Porta, D. \& Keating, M. (2019). Sosyal bilimlerde kaç yaklaşım var? (S. Gürses, Çev.). D. della Porta ve M. Keating (Ed.). Epistemolojik bir giriş. Sosyal bilimlerde yaklaşımlar ve metodolojiler çoğulcu bir perspektif (s. 38-60) içinde. İstanbul: Küre Yayınları.

Robson, C. (2017). Bilimsel araştırma yöntemleri gerçek dünya araştırmaları (Ş. Çımkır ve N. Demirkasımoğlu, Çev. Ed.). Ankara: Anı Yayıncılık.

Punch, K. F. (2016). Sosyal araştırmalara giriş nicel ve nitel yaklaşımlar (D. Bayrak, H.B. Arslan ve Z. Akyüz, Çev.). Ankara: Siyasal Kitapevi.

Russell, B. (2019). Bilimsel bakış (F. Sezer, Çev.). İstanbul: Say Yayınları.

Saldana, (2011). Fundamentals of qualitative research. Oxford: Oxford University Press.

Sayer, A. (2019). Sosyal bilimlerde yöntem -Realist bir yaklaşım (S. Gürses, Çev.). İstanbul: Küre Yayinlar1.

Silverman, D. (2019). Nitel verileri yorumlama (E. Dinç, Çev.Ed.). Ankara: Pegem Akademi.

Stake, R. (1995). The arts of case study research. Thousand Oaks, California: Sage Publication.

TR Dizin Dergi Listesi (2019, 2 Kasım). Erişim adresi: https://trdizin.gov.tr/statistics/listAcceptedJournals.xhtml

Weber, M. (2017). Sosyal bilimler metodolojisi. (V. S. Öğütle, çev.). İstanbul: Küre Yayınları

Whitfield, P. (2018). Batı biliminde dönüm noktaları. (S. Uslu, Çev.) İstanbul: Küre Yayınları

Yıldırım, A. ve Şimşek, H. (2016). Sosyal bilimlerde nitel araştırma yöntemleri. (10. baskı). Ankara: Seçkin Yayıncılık.

Yin, R. K. (2017). Durum çalışması araştırması uygulamaları (İ. Günbayı, Çev.). Ankara: Nobel Akademik Yayınc1lık.

\section{Extended Abstract}

\section{Introduction}

This study focuses on determining the qualification levels and methodological analysis of articles with a qualitative research approach. The main purpose of this research is to reveal how the method part of the articles that are stated to be made with qualitative research method is explained. In this way, it is aimed to have an idea about the quality levels and method analysis of the articles. Considering the increasing interest in qualitative approach in educational research and the problems that researchers experience in the application process of the method, this study is important in terms of providing synthesis information about the field. In this context, methodological analysis of articles prepared using qualitative research methods was made.

\section{Methodology}

Qualitative research approach is more suitable for the essence of social research thanks to its originality and flexibility. The study in which the qualitative approach is adopted has single-case embedded design. It is 187 articles prepared in qualitative approach, published in the first issue of 2019 journals and social sciences journal published in TR Directory Social and Humanities Database Journal List, which is determined by maximum variation sampling and criterion sampling techniques, which are among the sampling types for study groups. Study data were analyzed by descriptive analysis and content analysis. Inclusion and exclusion criteria were determined in determining the research working group, and data were collected from journals with different characteristics in the context of these criteria. In this way, the data source has been diversified. The articles reviewed were accessed through the journals they were published in, and their originality was confirmed. The method parts of the examined articles were carefully read by the researcher. The data obtained were coded in accordance with the thematic data form prepared by the researcher. The data analyzed and arranged in a thematic framework were recorded in computer environment. It was aimed to provide a comprehensive and holistic analysis by using descriptive analysis and content analysis together in the analysis of the data. The study was suspended for more than three months, and the method sections of the articles were carefully read, the data was 
coded, and the entire analysis process was repeated, as in the first analysis phase. The reliability / credibility of the study was tried to be increased by comparing the findings obtained from the first and second analysis. The first coding and analysis process of the study was carried out in December-January 2019, the second coding and analysis process was carried out in May-June 2020. Percentage of agreement between codes was determined using the Miles \& Huberman formula. Accordingly, the integrity value between codes is $99 \%$. Data analysis, first and second coding, accessing from codes to themes, networking between themes, integration and interpretation were carried out meticulously, scientifically, and systematically. The analysis process of the data was explained in detail, and all dimensions of how the results were reached were revealed. Throughout the research, the analysis process was spirally controlled by consulting experts at every stage. Raw data and analysis are preserved for reanalysis. Findings obtained in the research were reported in accordance with scientific ethical rules.

\section{Findings and Discussion}

It was determined that different qualitative designs were used in the articles examined within the scope of the study. In most of the articles examined, sufficient explanation was not given regarding the pattern used. In some studies, designs have been misnamed. Theoretical explanations of the pattern are incomplete or inaccurate. However, some studies did not include pattern information. In the examined articles, it was seen that the concepts of data collection methods, data collection tools and the development processes of data collection tools were used interchangeably. In the results of the research data collection tools, it was seen that the data collection tools were diversified. However, in some of the reviewed articles, theoretical, explanatory, and clear information about data collection tools could not be reached. In some of the studies examined, it was seen that quantitative analysis techniques were used together with qualitative data analysis techniques. This is a natural consequence of the use of quantitative data collection tools. In some of the articles examined, information on data analysis was not available. It was determined that there were problems in terms of compliance with qualitative research methods in a significant part of the articles examined. This situation can be interpreted that the studies are not qualitatively sufficient.

\footnotetext{
*Yazarlar makaleye eşit oranda katkı sağlamış olduklarını beyan ederler.
} 